\title{
Michael Wintroub.
}

\section{A Savage Mirror: Power, Identity, and Knowledge in Early Modern France.} Stanford: Stanford University Press, 2006. Pp. xii, 306

Michael Wintroub offers an extensively researched and thoughtful look at Henri II's 1550 royal entry into the city of Rouen, France. His initial site of investigation is a Brazilian village that was recreated in Rouen specifically for the entry. The village came complete with natives brought from Brazil to battle against each other; by all accounts the king was impressed with this spectacle and the others that were produced by the entry festival organizers. Wintroub examines how this tableau vivant signalled French understandings of the Other, and deftly analyzes the additional philosophies, traditions, and rituals that were simultaneously referenced. Indeed, the festival entry offers tantalizing clues with regard to local lobbying for support in trade with Brazil; efforts to educate the king in the tradition of the speculum principis; humanist notions of progress, eloquence, and personal achievement; cultural elitism among the Rouen citizenry; messianic beliefs and the search for paradise; the ancient ritual of the triumph and its connection to Christ's entry into Jerusalem; and the sixteenth-century European fascination with wonder cabinets and relics.

LAURA SCHECHTER, University of Alberta

\section{Constance M. Furey.}

\section{Erasmus, Contarini, and the Religious Republic of Letters.}

Cambridge and New York: Cambridge University Press, 2006. Pp. xiv, 255.

Like a skilled art restorer, Professor Furey reveals new contours in figures whose once shining countenance has become dimmed with age. Nuanced, well-informed, and thoroughly well-written, her vision of sixteenth-century Christian humanists as they attempted to create an alternative to the sterility of scholastic theology on the one hand and cynical power politics on the other lays out, in five short chapters, a most persuasive case for the "religious republic of letters." Furey is at her best when presenting the fracture zones between politics and learning, learning and piety, and gendered and non-gendered experience. Confronted by the demands of both faith and their social positions (in each, withdrawal from the world is not an option, although it is often a fleeting temptation), Furey's "pious literati" -Erasmus, More and his daughter Margaret, Colonna, Contarini, and Pole-explored the limits of learning and the bonds of a shared quest. Their solution lay in their notion of spirit- 